\title{
The Effect of Abscisic Acid in the Conversion of Cocoa Somatic Embryos into Plantlets
}

\author{
A. K. Quainoo", ${ }^{1, *}$ I. B. Dwomon ${ }^{2}$ \\ ${ }^{1}$ Department of Biotechnology, Faculty of Agriculture, University for Development Studies, Ghana \\ ${ }^{2}$ Department of Agronomy, Faculty of Agriculture, University for Development Studies, Ghana
}

\begin{abstract}
The effects of abscisic acid (ABA) $\left(0,10,30\right.$ and $\left.50 \mu \mathrm{Ml}^{-1}\right)$ in embryo development (ED) medium on the conversion of primary and secondary somatic embryos of cocoa at different developmental stages (globular, heart and torpedor) were evaluated in order to overcome the low rate of conversion into plantlets. Genotype COCA 3370-5 was more efficient than genotype AMAZ 3-2 in terms of embryogenesis and response to ABA treatments with secondary embryogenesis being superior over primary embryogenesis. Torpedor stage embryos were more efficient than globular and heart stage embryos in converting into plantlets. The most effective treatments for embryo conversion were 0 and $10 \mu \mathrm{Ml}^{-1} \mathrm{ABA}$ at 2 weeks (wk). ABA concentrations at 0 and $10 \mu \mathrm{Ml}^{-1}$ were more effective in converting primary and secondary somatic embryos into plantlets than the 30 and $50 \mu \mathrm{Ml}^{-1}$. The effects of ABA treatments on conversion of secondary somatic embryos into plantlets were superior to primary embryos. Time of ABA treatment in ED medium influenced the conversion of the somatic embryos. ABA treatments at 0 and $10 \mu \mathrm{Ml}^{-1}$ recorded decreasing embryo conversion rates from two to six wk, the other treatments recorded higher conversion rates at four wk followed by two and six wk respectively.
\end{abstract}

Keywords Abscisic Acid, Cocoa, Somatic Embryos, Primary and Secondary Embryogenesis

\section{Introduction}

Tissue culture technique such as somatic embryogenesis has been routinely used both as a means of propagation, as well as a valuable model for investigating the structural, physiological and molecular events occurring during embryo development (Stasolla and Yeung, 2003). The major problems associated with in vitro embryogenesis include: low number of embryos generated and low frequency of mature embryos able to convert into viable plantlets. Despite the fact that embryogenesis is comprised of a sequence of defined steps which include proliferation of embryogenic tissues, embryo maturation and germination, attempts at improving the whole procedure have been made almost exclusively during the maturation stage (Stasolla and Yeung, 2003). This strategy was based on the assumption that successful regeneration is related to the treatments provided during the development of the embryos. Major optimisation of the maturation medium have involved judicious selections of the type and concentration of growth regulators, namely abscisic acid (ABA) (Stasolla and Yeung, 2003).

The maturation process in culture is initiated with the development of the somatic embryos and terminates with the imposed desiccation prior to germination. For complete

\footnotetext{
* Corresponding author:

aquainoo@googlemail.com (A. K. Quainoo)

Published online at http://journal.sapub.org/fs

Copyright (C) 2012 Scientific \& Academic Publishing. All Rights Reserved
}

maturation to occur, embryos must achieve both morphological and physiological maturity (Stasolla and Yeung, 2003). Fully developed somatic embryos can reach morphological maturity but cannot successfully germinate and convert into viable plantlets unless they undergo a desiccation period. It is during desiccation that embryos reach physiological maturity (Kermode, 1990). ABA is linked with the initiation of the maturation pathway and inhibition of precocious growth (Rock et al., 1995).

Accumulation of storage products is an important event during embryogenesis. In white spruce, starch accumulates first, followed by lipids and proteins (Joy et al., 1991). ABA is known to be important for the accumulation of storage reserves (Marion-Poll, 1997) 1997). In recent years, unique gene products associated with the development of quiescence have been found. The expression of these genes can be increased or decreased by ABA (Rock et al., 1995). Towards the latter third of seed development in both monocots and dicots, a set of gene products begin to accumulate in the embryos. These include a variety of protein products such as lectin, amylase inhibitor, lipid bodies, membrane protein, storage proteins and uncharacterised proteins. These protein bodies appear at the time the embryo acquire the ability to withstand desiccation (Rock et al., 1995). Therefore, a proposed function of ABA in embryos in addition to promoting embryogenesis and preventing germination is to regulate the synthesis of proteins involved in desiccation tolerance.

In addition, $\mathrm{ABA}$ also plays an important role in the regulatory mechanism involved in seed development and 
subsequent germination (Kermode, 1990). Exogenous ABA application has also been used to enhance desiccation tolerance in somatic embryos of a diverse range of species including white spruce (Attree et al., 1991), alfalfa (Lecouteux et al., 1993), Havea brasiliensis (Linossier et al., 1997), cassava (Groll et al., 2002) and tea (Mondal et al., 2002)

Furthermore, structural abnormality of somatic embryos is linked to low conversion into plant (Rodriguez and Wetzstein, 1994; Soh et al., 1996). It has been reported that 2,4 - D and cytokinins increase abnormal somatic embryos in Aralia cordata (Lee and Soh, 1994) but ABA enhances development of normal embryos in caraway, and carrot (Kamada and Harada, 1981). Moreover it is known that the conversion rate of somatic embryos to plantlets is promoted (by ABA treatment) in alfalfa and carrot (Fujii et al., 1990, Nickle and Jeung, 1993). In carrot, the conversion frequencies were higher for somatic embryos ranging from globular to cotyledonary stages cultured in medium with $50 \mu \mathrm{M}$ ABA than those cultured on plant growth regulators free medium (Lee et al., 2002).

Although ABA has been implicated in normalizing development, studies that specifically investigated the conversion of cocoa somatic embryos are lacking. In this research, the effects of $\mathrm{ABA}$ treatment on the conversion of primary and secondary somatic embryos to plantlets were evaluated. The aim was to improve the conversion of somatic embryos of cocoa into plantlets. Signs of abnormalities on the embryos as a result of ABA treatment were observed.

\section{Materials and Methods}

\subsection{Production of Somatic Embryos}

Two cocoa genotypes (AMAZ 3-2 and COCA 3370-5) were sources for primary and secondary somatic embryo production. Somatic embryos were initiated from floral explants collected at the University of Reading Intermediate Cocoa Quarantine Unit following the protocol of Li et al. (1998) and Maximova et al. (2002). Primary and secondary somatic embryos were randomly harvested from the cultures and used in all trials. They were maintained inside $9 \mathrm{~cm}$ Petri dishes containing $25 \mathrm{ml}$ embryo development (ED) medium comprising DKW basal salts, $100 \mathrm{mg} / \mathrm{l}$ myo-inositol, $2 \mathrm{mg} / 1$ thiamine- $\mathrm{HCl}, 1 \mathrm{mg} / 1$ nicotinic acid, $2 \mathrm{mg} / 1$ glycine, $30 \mathrm{~g} / 1$ sucrose, $1 \mathrm{~g} / 1$ glucose, and $2 \mathrm{~g} / 1$ Phytagel, pH 5.7 (Li et al., 1998).

\subsection{Effect of ABA on the Conversion of Somatic Embryos at Different Developmental Stages into Plantlets}

The ED medium was enriched with different concentrations of $\mathrm{ABA}(0,10,30$ and $50 \mu \mathrm{M})$. The $\mathrm{ABA}$ was filter-sterilized through $0.22 \mu \mathrm{Ml}^{-1}$ Millipore filters and added to the media after autoclaving. Ten batches of somatic embryos (primary and secondary embryos used separately) per plate were used throughout the experiment. Somatic embryos from the two genotypes at different developmental stages (globular, heart and torpedor) were isolated and placed on the ED medium in $9 \mathrm{~cm}$ Petri dishes. After two weeks (wk) the embryos were transferred to primary embryo conversion medium (PEC) for regeneration into plantlets.

\subsection{Effect of ABA Treatment Time on Conversion of Somatic Embryos into Plantlets}

Primary and secondary somatic embryos at torpedor stage of development were used as described above. Torpedor staged embryos recorded higher conversion rates than globular and heart staged embryos. The embryos were plated on ED medium enriched with different concentrations of $\operatorname{ABA}\left(0 \mu \mathrm{Ml}^{-1}, 10 \mu \mathrm{Ml}^{-1}, 30 \mu \mathrm{Ml}^{-1}\right.$ and $\left.50 \mu \mathrm{Ml}^{-1}\right)$ for two, four and six wk respectively. The embryos were then transferred to PEC for regeneration into plantlets.

200 somatic embryos per genotype per treatment of ten embryos per plate were used. Conversion was assessed as the percentage of embryos manifesting normal new tissue growth. All the cultures were kept for a minimum of four months before being designated as non-surviving.

\subsection{Abnormal Somatic Embryos and Plantlets}

Somatic embryos subjected to ABA treatments and plantlets were observed for signs of phenotypic abnormalities. Only normal somatic embryos were allowed to convert into plantlets.

\subsection{Plantlet Regeneration}

The conversion of somatic embryos to plantlets was conducted under $16 \mathrm{~h}$ photoperiod $\left(90 \mu \mathrm{mol} \mathrm{m}-^{2} \mathrm{~s}^{-1}\right.$ irradiance) at $22^{\circ} \mathrm{C}$. Surviving somatic embryos were placed in $250 \mathrm{ml}$ glass jars containing $40 \mathrm{ml}$ primary embryo conversion (PEC) medium which comprised DKW basal salts, 100 $\mathrm{mg} / \mathrm{l}$ myo-inositol, $2 \mathrm{mg} / \mathrm{l}$ thiamine- $\mathrm{HCl}, 1 \mathrm{mg} / \mathrm{l}$ nicotinic acid, $2 \mathrm{mg} / \mathrm{l}$ glycine, $0.3 \mathrm{~g} / 1 \mathrm{KNO}, 0.435 \mathrm{mg} / \mathrm{l}$ arginine, $0.187 \mathrm{mg} / 1$ glycine, $0.328 \mathrm{mg} / \mathrm{l}$ leucine, $0.456 \mathrm{mg} / \mathrm{l}$ lysine, $0.51 \mathrm{mg} / 1$ tryptophane, $10 \mathrm{~g} / 1$ sucrose, $20 \mathrm{~g} / 1$ glucose, and $1.75 \mathrm{~g} / \mathrm{l}$ Phytagel, pH 5.8 (Young et al., 2000). PEC medium was renewed every 20 days until the appearance of plants with true leaves and roots.

\subsection{Acclimatization of Plantlets}

Healthy plantlets containing two or more true leaves were weaned in the glasshouse. The plantlets were carefully removed from the culture vessels with forceps and washed in warm water to remove the culture medium. The plantlets were then placed individually in 4 inches diameter plastic pots containing mixture of 3:1 SHL seed sowing compost (Sinclair, UK) and vermiculite, watered until the compost was saturated. The potted plantlets were placed in propagators under shade and the vent gradually opened one week (wk) after culture. After one month, the successfully weaned plantlets were fed with Sangral liquid fertilizer (1:1:1 NPK, Sinclair, UK) once every month. Plantlets with two or more 
true leaves and healthy roots were weaned in the glasshouse. The number of plantlets successfully weaned (four month after conversion into plantlets) was recorded.

\section{Results}

Table 1. Somatic embryogenesis of cocoa genotypes

\begin{tabular}{|c|c|c|}
\hline Genotypes & $\begin{array}{c}\text { Embryogenesis } \\
\text { frequency (\%) }\end{array}$ & $\begin{array}{c}\text { Mean no. of embryos } \\
\text { per cotyledon }( \pm \mathrm{Se})\end{array}$ \\
\hline \multicolumn{3}{|c|}{ Primary somatic embryos } \\
\hline AMAZ 3-2 & 38.45 & $2.92 \pm 1.28$ \\
\hline COCA3370-5 & 49.21 & $3.76 \pm 2.03$ \\
\hline LSD & 4.58 & 0.91 \\
\hline \multicolumn{3}{|c|}{ Secondary somatic embryos } \\
\hline AMAZ 3-2 & 51.40 & $3.36 \pm 2.58$ \\
\hline COCA3370-5 & 64.47 & $6.43 \pm 2.64$ \\
\hline LSD & 6.36 & 2.45 \\
\hline
\end{tabular}

Data was collected eight wk after culture initiation $(\mathrm{n}=60)$. LSD is the significant difference between two means in a column at $5 \%$ probability.

\subsection{Frequency of Embryogenesis of Cocoa Genotypes}

Data on primary and secondary embryogenesis for the two experimental genotypes are shown in Table 1. The explant materials were variable in embryogenesis.

\subsection{Effects of ABA on Somatic Embryo Development}

The ABA concentrations influenced the conversion of different developmental stages of somatic embryos into plantlets. Torpedor stage embryos were more efficient converting into plantlets as presented in Table 2.

\subsection{Effects of ABA Pre-Culture Time on Somatic Embryo Development}

The concentration and time of ABA exposure did improve the conversion of somatic embryos into plantlets. ABA concentrations at 0 and $10 \mu \mathrm{Ml}^{-1}$ seem to have similar effect on the conversion of embryos to plantlets (Table 3 ).

Table 2. Effects of ABA preculture concentrations and somatic embryos conversion

\begin{tabular}{|c|c|c|c|c|c|c|c|}
\hline \multicolumn{8}{|c|}{ Developmental stages by } \\
\hline \multirow{2}{*}{$\begin{array}{c}\text { Treatment } \\
\text { (ABA) }\end{array}$} & \multirow{2}{*}{$\begin{array}{l}\text { No. of somatic } \\
\text { embryos tested }\end{array}$} & \multicolumn{3}{|c|}{ COCA 3370-5 } & \multicolumn{3}{|c|}{ AMAZ 3-2 } \\
\hline & & globular & heart & torpedor & globular & heart & torpedor \\
\hline \multicolumn{8}{|c|}{ Primary somatic embryos } \\
\hline $0 \mu \mathrm{ml}^{-1}$ & 200 & $28(14 \%)$ & $42(21 \%)$ & $82(41 \%)$ & $8(4 \%)$ & $14(7 \%)$ & $41(21 \%)$ \\
\hline $10 \mu \mathrm{ml}^{-1}$ & 200 & $30(15 \%)$ & $42(21 \%)$ & $88(44 \%)$ & $10(5 \%)$ & $17(9 \%)$ & $43(22 \%)$ \\
\hline $30 \mu \mathrm{ml}^{-1}$ & 200 & $12(6 \%)$ & $30(15 \%)$ & $36(18 \%)$ & $4(2 \%)$ & $6(3 \%)$ & $16(8 \%)$ \\
\hline $50 \mu \mathrm{ml}^{-1}$ & 200 & $8(4 \%)$ & $18(9 \%)$ & $20(10 \%)$ & $2(1 \%)$ & $0(0 \%)$ & $6(3 \%)$ \\
\hline Total & 800 & - & - & - & - & - & - \\
\hline LSD & & 5.33 & 5.92 & 6.68 & 3.74 & 3.18 & 4.10 \\
\hline \multicolumn{8}{|c|}{ Secondary somatic embryos } \\
\hline $0 \mu \mathrm{ml}^{-1}$ & 200 & $36(18 \%)$ & $58(29 \%)$ & $114(57 \%)$ & $14(7 \%)$ & $24(12 \%)$ & $66(33 \%)$ \\
\hline $10 \mu \mathrm{ml}^{-1}$ & 200 & $38(19 \%)$ & $58(29 \%)$ & $116(58 \%)$ & $20(10 \%)$ & $26(13 \%)$ & $66(33 \%)$ \\
\hline $30 \mu \mathrm{ml}^{-1}$ & 200 & $20(10 \%)$ & $38(19 \%)$ & $46(23 \%)$ & $6(3 \%)$ & $14(7 \%)$ & $26(13 \%)$ \\
\hline $50 \mu \mathrm{ml}^{-1}$ & 200 & $14(7 \%)$ & $20(10 \%)$ & $26(13 \%)$ & $0(0 \%)$ & $6(3 \%)$ & $14(7 \%)$ \\
\hline Total & 800 & - & - & - & - & - & - \\
\hline LSD & & 6.21 & 7.13 & 10.54 & 5.89 & 6.19 & 8.02 \\
\hline
\end{tabular}

200 somatic embryos per genotype per treatment were used. LSD is the significant difference between two means in a column at $5 \%$ probability.

Table 3. Effect of ABA treatment time on conversion of somatic embryos into plantlets

\begin{tabular}{|c|c|c|c|c|c|c|c|}
\hline \multicolumn{8}{|c|}{ Torpedor stage embryos } \\
\hline \multirow{2}{*}{$\begin{array}{c}\text { Treatment } \\
\text { (ABA) }\end{array}$} & \multirow{2}{*}{$\begin{array}{l}\text { No. of somatic } \\
\text { embryos tested }\end{array}$} & \multicolumn{3}{|c|}{ COCA $3370-5$} & \multicolumn{3}{|c|}{ AMAZ 3-2 } \\
\hline & & $2 \mathrm{wk}$ & $4 \mathrm{wk}$ & $6 \mathrm{wk}$ & $2 \mathrm{wk}$ & $4 \mathrm{wk}$ & $6 \mathrm{wk}$ \\
\hline \multicolumn{8}{|c|}{ Primary somatic embryos } \\
\hline $0 \mu \mathrm{ml}^{-1}$ & 200 & $82(41 \%)$ & $78(39 \%)$ & $70(35 \%)$ & $42(21 \%)$ & $36(18 \%)$ & $32(16 \%)$ \\
\hline $10 \mu \mathrm{ml}^{-1}$ & 200 & $86(43 \%)$ & $82(41 \%)$ & $74(37 \%)$ & $48(24 \%)$ & $44(22 \%)$ & $38(19 \%)$ \\
\hline $30 \mu \mathrm{ml}^{-1}$ & 200 & $28(14 \%)$ & $36(18 \%)$ & $22(11 \%)$ & $24(12 \%)$ & $28(24 \%)$ & $22(11 \%)$ \\
\hline $50 \mu \mathrm{ml}^{-1}$ & 200 & $8(4 \%)$ & $26(18 \%)$ & $14(7 \%)$ & $6(3 \%)$ & $14(7 \%)$ & $10(5 \%)$ \\
\hline Total & 800 & - & - & - & - & - & - \\
\hline LSD & & 9.74 & 10.53 & 9.62 & 7.66 & 7.38 & 6.57 \\
\hline \multicolumn{8}{|c|}{ Secondary somatic embryos } \\
\hline $0 \mu \mathrm{ml}^{-1}$ & 200 & $110(55 \%)$ & $106(53 \%)$ & $100(50 \%)$ & $70(35 \%)$ & $66(33 \%)$ & $64(32 \%)$ \\
\hline $10 \mu \mathrm{ml}^{-1}$ & 200 & $116(58 \%)$ & $112(56 \%)$ & $104(52 \%)$ & $66(33 \%)$ & $74(37 \%)$ & $64(32 \%)$ \\
\hline $30 \mu \mathrm{ml}^{-1}$ & 200 & $44(22 \%)$ & $54(27 \%)$ & $36(18 \%)$ & $36(18 \%)$ & $42(21 \%)$ & $34(17 \%)$ \\
\hline $50 \mu \mathrm{ml}^{-1}$ & 200 & $10(5 \%)$ & $34(17 \%)$ & $24(12 \%)$ & $10(5 \%)$ & $20(10 \%)$ & $14(7 \%)$ \\
\hline Total & 800 & - & - & - & - & - & - \\
\hline LSD & & 12.93 & 11.29 & 10.96 & 9,43 & 8.60 & 7.73 \\
\hline
\end{tabular}


Table 4. Conversion of somatic embryos into plantlets

\begin{tabular}{|c|c|c|c|c|c|}
\hline & & \multicolumn{2}{|c|}{ No. of embryos converted } & \multicolumn{2}{|c|}{ Plantlets weaned in glasshouse } \\
\hline $\begin{array}{l}\text { Treatment } \\
\text { (ABA) }\end{array}$ & $\begin{array}{c}\text { Total no. of embryos } \\
\text { tested }\end{array}$ & $\begin{array}{c}\text { Primary somatic } \\
\text { embryos }\end{array}$ & $\begin{array}{c}\text { Secondary somatic } \\
\text { embryos }\end{array}$ & $\begin{array}{c}\text { Primary somatic } \\
\text { embryos }\end{array}$ & $\begin{array}{c}\text { Secondary somatic } \\
\text { embryos }\end{array}$ \\
\hline \multicolumn{6}{|c|}{ COCA 3370-5 } \\
\hline $0 \mu \mathrm{ml}^{-1}$ & 600 & $230(39.67 \%)$ & $316(52.67 \%)$ & $125(20.83 \%)$ & $159(26.5 \%)$ \\
\hline $10 \mu \mathrm{ml}^{-1}$ & 600 & $242(40.3 \%)$ & $332(55.33 \%)$ & $128(21.33 \%)$ & $172(28.67 \%)$ \\
\hline $30 \mu \mathrm{ml}^{-1}$ & 600 & $86(14.33 \%)$ & $134(22.33 \%)$ & $35(5.83 \%)$ & $81(13.5 \%)$ \\
\hline $50 \mu \mathrm{ml}^{-1}$ & 600 & $48(8 \%)$ & $68(11.33 \%)$ & $18(3 \%)$ & $30(5 \%)$ \\
\hline Total & 2400 & - & - & - & - \\
\hline LSD & & 36.94 & 44.38 & 19.49 & 22.71 \\
\hline \multicolumn{6}{|c|}{ AMAZ 3-2 } \\
\hline $0 \mu \mathrm{ml}^{-1}$ & 600 & $110(18.33 \%)$ & $200(33.33 \%)$ & $44(7.33 \%)$ & $82(13.67 \%)$ \\
\hline $10 \mu \mathrm{ml}^{-1}$ & 600 & $120(20 \%)$ & $204(34 \%)$ & $42(7 \%)$ & $96(16 \%)$ \\
\hline $30 \mu \mathrm{ml}^{-1}$ & 600 & $74(12.33 \%)$ & $112(18.67 \%)$ & $23(3.83 \%)$ & $70(11.67)$ \\
\hline $50 \mu \mathrm{ml}^{-1}$ & 600 & $30(5 \%)$ & $44(7.33 \%)$ & $14(2.33 \%)$ & $20(3.33 \%)$ \\
\hline Total & 2400 & - & - & - & - \\
\hline LSD & & 20.82 & 31.28 & 11.76 & 16.55 \\
\hline
\end{tabular}

600 somatic embryos per genotype per treatment were used. LSD is the significant difference between two means in a column at $5 \%$ probability. medium (left) $(\mathrm{bar}=3 \mathrm{~cm})$.

\section{Discussion}

Cocoa genotypes responded differently to embryogenesis as genotype COCA $3370-5$ was more efficient than genotype AMAZ 3-2 (Table 1). This may be attributed to their genetic make up. Secondary embryogenesis was superior over primary embryogenesis in terms of frequency of embryogenesis and the number of embryos generated per cotyledon. This may be attributed to the fact that secondary embryos originated from unicellular cells while primary embryos originated from multicellular cells (Maximova et al., 2002).

\subsection{Effects of ABA on Somatic Embryo Development}

The developmental stages of somatic embryos affected the conversion of embryos into plantlets. Generally secondary somatic embryos were efficient than primary somatic embryos (Table 2). Torpedor stage embryos were more efficient than globular and heart stage embryos in converting into plantlets. ABA was effective in promoting the conversion of primary and secondary somatic embryos into plantlets. ABA concentrations at 0 and $10 \mu \mathrm{Ml}^{-1}$ significantly influenced the conversion of embryos into plantlets than the 30 and 50 $\mu \mathrm{Ml}^{-1}$ with secondary embryos being superior (Table 2). These conform to the findings of Baochun and Wolyn (1996). However, there were no significant difference between ABA concentrations at 0 and $10 \mu \mathrm{Ml}^{-1}$ on the conversion of somatic embryos into plantlets. Generally, somatic embryos of genotype COCA 3370-5 were more efficient converting into plantlets than somatic embryos of genotype AMAZ 3-2 after treatment with ABA (Table 2).

\subsection{Effects of ABA Pre-Culture Time on Somatic Embryo Development}

Generally, the effect of ABA concentrations on the conversion of somatic embryos into plantlets decreased with time with genotype COCA 3370-5 been efficient than genotype AMAZ 3-2 (Table 3). ABA concentrations at 0 and $10 \mu \mathrm{Ml}^{-1}$ with time seem to be significantly efficient than
ABA treatments at 30 and $50 \mu \mathrm{Ml}^{-1}$ in the conversion of somatic embryos into plantlets. While ABA concentrations at 0 and $10 \mu \mathrm{Ml}^{-1}$ recorded decreasing embryo conversion rates from two to six wk, ABA treatments at 30 and $50 \mu \mathrm{Ml}^{-1}$ recorded higher conversion rates at four wk respectively for the two genotypes (Table 3).

The outcome of these results indicates that $\mathrm{ABA}$ treatment at $10 \mu \mathrm{ml}^{-1}$ over four wk did improve the conversion of primary and secondary somatic embryos into plantlets. These observations were general across the genotypes (AMAZ 3-2 and COCA 3370-5) although COCA 3370-5 was more efficient in converting into plantlets (Table 3 ).

\subsection{Abnormalities and Glasshouse Establishment of Plantlets}

All the ABA treatments including the controlled experiment generated abnormal plantlets. These abnormalities were generally depicted as plantlets with thickened leaves, blackened leaves, elongated and thin shoots, and hair-less roots. The 30 and $50 \mu \mathrm{Ml}^{-1} \mathrm{ABA}$ treatments generated mainly plantlets with blackened leaves with distorted shoots (figure 1) which maybe attributed to the high concentrations of the ABA. Although there were no morphological differences in the plantlets weaned in the glasshouse ABA treated plantlets at $10 \mu \mathrm{Ml}^{-1}$ seems to establish better (Table 4). This conforms with the findings of Ruffoni et al., (1999) in which ABA increased the conversion of somatic embryos of Genista monosperma into plantlets. Morphologically there were no differences in glasshouse weaned plants derived from $\mathrm{ABA}$ treated medium and non ABA treated medium (figure 2 ), however, the number of abnormal somatic embryos increased with the concentration of the ABA.

\section{Conclusions}

Results of this research suggest that one does not require the presence of $\mathrm{ABA}$ in the medium to generate successful plantlets. Hence, the cost of ABA in such works can be saved. 
Again since ABA concentration at $10 \mu \mathrm{Ml}^{-1}$ in terms of somatic embryo conversion numbers seem to be better than ABA concentration at $0 \mu \mathrm{Ml}^{-1}$ it would be interesting to include a concentration levels of $5 \mu \mathrm{Ml}^{-1}$ in future investigations.

\section{ACKNOWLEDGEMENTS}

This work was supported by a scholarship from the Ghana government. A. K. Quainoo is grateful to Dr A. C. Wetten for his friendship and supervision of his Ph.D research and Professor Paul Hadley for the use of facilities at the University of Reading Cocoa Intermediate Quarantine Unit.

\section{REFERENCES}

[1] Attree, S. D., Moore, D., Sawhney, V. K. and Fowke, L. C., (1991) Enhanced maturation and disiccation tolerance of white spruce [Picea glauca (Moench) Voss] somatic embryos: effects of a non-plasmolyzing water stress and abscisic acid. Annals of Botany, 68: 519-525.

[2] Baochun, L. and Wolyn, D. J., (1996) Abscisic acid and ancymidol promote conversion of somatic embryos to plantlets and secondary embryogenesis in Asparagus officinalis L. In Vitro Cellular \& Developmental Biology - Plant, 32(Number 4): 223-226.

[3] Groll, J., Mycock, D. J. and Gray, V. M., (2002) Effect of medium salt concentration on differentiation and maturation of somatic embryos of cassava (Manihot esculenta Crantz). Annals of Botany, 89: 645-648.

[4] Joy, I. V. R. W., Yeung, E. C., Kong, L. and Thorpe, T. A. D., (1991) Development of white spruce somatic embryos: Storage product deposition. In vitro Cell Dev. Biol-Plant, 27: $32-41$.

[5] Kamada, H. and Harada, H., (1981) Changes in endogenous levels and effects of abscisic acid during somatic embryogenesis. Plant Cell Physiology, 22: 1423-1429.

[6] Lecouteux, C., Lai, F. M. and Mckersie, B. D., (1993) Maturation of somatic embryos by abscisic acid, sucrose and chilling. Plant Science, 87: 69-77.

[7] Lee, K. S., Lee, J. C. and Soh, W. Y., (2002) High frequency plant regeneration from Aralia cordata somatic embryos. Plant Cell, Tissue and Organ Culture, 68: 241-246.

[8] Lee, K. S. and Soh, W. Y., (1994) Effect of abscisic acid on the number of somatic embryo cotyledons in tissue cultures of Aralia cordata Thunb. Korean Journal of Plant Tissue Culture, 21: 287-291.

[9] Li, Z., Traore, A., Maximova, S. and Guiltinan, M., (1998) Somatic embryogenesis and plant regeneration from floral explants of cacao (Theobroma cacao L.) using thidiazuron. In vitro Cellulara and Developmental Biology-Plants, 34: 293-299.

[10] Linossier, L., Veisseire, P., Cailloux, F. and Coudret, A., (1997) Effects of abscisic acid and high concentrations of PEG on Hevea brasiliensis somatic embryos development. Plant Sciences, 124: 183-191.

[11] Marion-Poll, A., (1997) ABA and seed development. Trends in Plant Sciences, 2: 447-448.

[12] Maximova, S. N., Alemanno, L., Young, A., Feffiere, N., Traore, A. and Guiltinan, M. J., (2002) Efficiency, genotypic variability, and cellular origin of primary and secondary somatic embryogenesis of Theobroma cacao L. In vitro Cellular and Developmental Biology-Plant, 38: 252-259.

[13] Mondal, T. K., Bhattacharya, A., Sood, A. and Ahuja, P. S., (2002) Factors affecting germination and conversion frequency of somatic embryos of Tea [Camellia sinensis]. Journal of Plant Physiology, 159: 1317-1321.

[14] Rodriguez, A. P. M. and Wetzstein, H. Y., (1994) The effect of auxin type and concentration on pecan (Carya illinoinensis) somatic embryo morphology and subsequent conversion into plant. Plant Cell Reports, 13: 607-611.

[15] Ruffoni, B., Rabaglio, M., Semeria, L. and Allavena, A., (1999) Improvement of micropropagation of Genista monosperma Lam. by abscisic acid treatment. Plant Cell, Tissue and Organ Culture, 57: 223-225.

[16] Soh, W. Y., Choi, D. Y. and Lee, E. K., (1996) Multicotyledonary structure of somatic embryos formed from cell cultures of Ducus carota L. Journal of Plant Biology, 39: 71-77.

[17] Stasolla, C. and Yeung, E. C., (2003) Recent advances in conifer somatic embryogenesis: improving somatic embryos quality, Kluwer Academic Publishers.

[18] Young, A., Miller, C., Antunez de Mayolo, G., Swanson, J. D., Pishak, S., S.N. Maximova, S. N. and Guiltinan, M. J. (2000) Cocoa Tissue Culture Protocol Book, Department of Horticulture, The Pennsylvania State University,. 